\title{
Resources of Boti Village (Timor Island) for the Ecotourism Development
}

\author{
Simon Suddin ${ }^{*}$ \\ Department of Architecture, Faculty of Science and Engineering, University of Nusa Cendana, Kupang, Indonesia
}

\begin{abstract}
The aim of the paper is to describe the natural and cultural resources of Boti community for tourism development in Boti Village in Timor Island, Indonesia. Boti has been known as the last kingdom in Timor Island and has visited by tourist to enjoy community live and green landscape in semi arid region in Timor Island. The Boti community has indigenous belief called halaika, and community daily life was organized and managed by a king called Usif. The basic philosophy of community who live in Boti was implemented in house structure, arrangement and philosophy (sonaf, ume kbubu, lopo), farming activity, and many daily activities. The uniqueness of Boti's nature and culture has potentiality to be developed as tourism attractions. The local wisdoms of local community in Boti influence the sustainable uses of resources, in which it is produces green and beauty forest landscape in Boti area. Eco-tourism seems to be potential form of tourism in Boti villages.
\end{abstract}

Keywords: Boti Village, ecotourism, indigenous community, local wisdom.

\section{INTRODUCTION}

Tourism is an important economic machine for many developing countries. In Indonesia, tourism contributes significantly in national and regional development. In many areas in Indonesia tourism has been developed to support local development. It is especially important in area with abundance natural and cultural resources. According to statistical data, tourism growth in Indonesia in 2014 reach 9.39\% compared to the previous years. Tourism contributes to the local economic development in many regions. Tourism was considered as an economic trigger for many sectors in recent development [1].

The benefit of tourism has been reported numerous. In the perspectives of economic aspect, tourism contributes to support national earning, increase local economic benefit, provides jobs, open opportunities for new business, and reduces poverty [2]. There are important aspect related to tourism-economic issues, namely tourism demand, tourism supply, market and governance to facilitate supplydemand and tourism stake-holders which are contributes to the tourism industry [3]. Tourist decision to visit some area has been identified related to some aspects, including attractions availability. There are also tourism products

\footnotetext{
${ }^{1}$ Correspondence address:

Simon Suddin

Email : simonsuddin57@gmail.com

Address : Dept. Architecture, University of Nusa Cendana, Jl. Adisucipto, Penfui-Kupang, Kupang
}

which are important to determine tourist to visit some destination [4].

In the perspective of economic, there are some benefits of tourism. It is including : tourism as agent to provides jobs opportunities, tourism opens opportunities to increase tax, tourism increase national revenue, tourism accelerate income equity, tourism increase adding value of cultural product, tourism enlarge market of domestic product; and tourism increase multiplier effect in economic sectors as an impact of tourism spending [5]. In social aspect, tourism contributes to increase education and training to increase human capacity. Scholar point out that tourism is a media to changes information, able to increase cultural and heritage preservation, increase local community capacity, decrease social conflict, and increase community creativity and innovation. In environmental aspect, tourism has been reported contributes to the environmental protection [6].

East Nusa Tenggara is an area with abundance natural and cultural resources but there still little utilization in tourism sectors $[7,8]$. In 2011, through the Master Plant for Acceleration and Development of National Economic year 2011-2025 which are established by central government, NTT with Bali and NTB was classified as zone 5 of economic corridors of development in Indonesia [9]. This provides opportunities for the development of Bali and lesser Sundas Island (West and East Nusa Tenggara Province) in development.

As far, Timor East Nusa Tenggara has 458 tourism attractions which are distributes to 22 
regencies and cities. The preferred tourism object was nature-based tourism destination, in which there are 115 objects (25\%) of the total of tourism object in East Nusa Tenggara. Potential tourism attractions are ranging from savanna, protected forest, cave, beach and hills. The highest number of tourism attraction is coastal area, in which there are about 104 of costal point. It is not surprises because East Nusa Tenggara has many islands and the length of coastline was about $5,700 \mathrm{~km}$. East Nusa Tenggara has 334 unit of tourism accommodation, ranging from star hotels, non star hotel, hostels. There are about 16 airports to support tourist arrivals to East Nusa Tenggara islands.

In the past five years, there are tendency of tourist arrivals increase in East Nusa Tenggara. Tourist was dominated by domestic tourist. It is become opportunities for East Nusa Tenggara to develop tourism. The aim of the paper is to describe the natural and cultural resources of Boti community for tourism development in Boti Village in Timor Island, Indonesia.

\section{MATERIAL AND METHOD}

In order to identify the social and environmental aspect of Boti, a primary and secondary data was collected. Primary data especially conducted at Boti Village through field observation and in depth interviews. An in depth interview with informal leader and member of community was implemented following standard methods. Author was accompanied with the family member of Usif (Boti king) to make appointment and facilitate in depth interviews implementation with Usif. Usif is the key person in this study to explore more story and information about the Boti community. An observation of rural environment was done through rapid rural resources appraisal.

Secondary data was collected through literature and document survey. Literature was collected from numerous office and library, both in local district and provincial office. The information generated from Usif and field evidence from observation activity was elaborated with literature sources. All of the generated and collected data was analyzed descriptively.

\section{RESULT AND DISCUSSION \\ Boti Tribal community}

Indigenous community in Timor-Tengah Selatan (TTS) Regency is Dawan, in which they live in core family system called Ume. They grow and form a small clan called pulunes or kuanes. Some of them, however, grow as a big clan called kanaf. The Ume lives in traditional house called lopo and ume (Fig. 1). Lopo is house for male and ume is house for female. The majority of community in TTS can be classified into three categories: (1) adat community (the traditional community with its own regulation), (2) agrobased community, and (3) transition community [10]. As many tribal communities in tropical regions, communication and transfer knowledge among member were flow by mouth communication and flow from generation to generation.
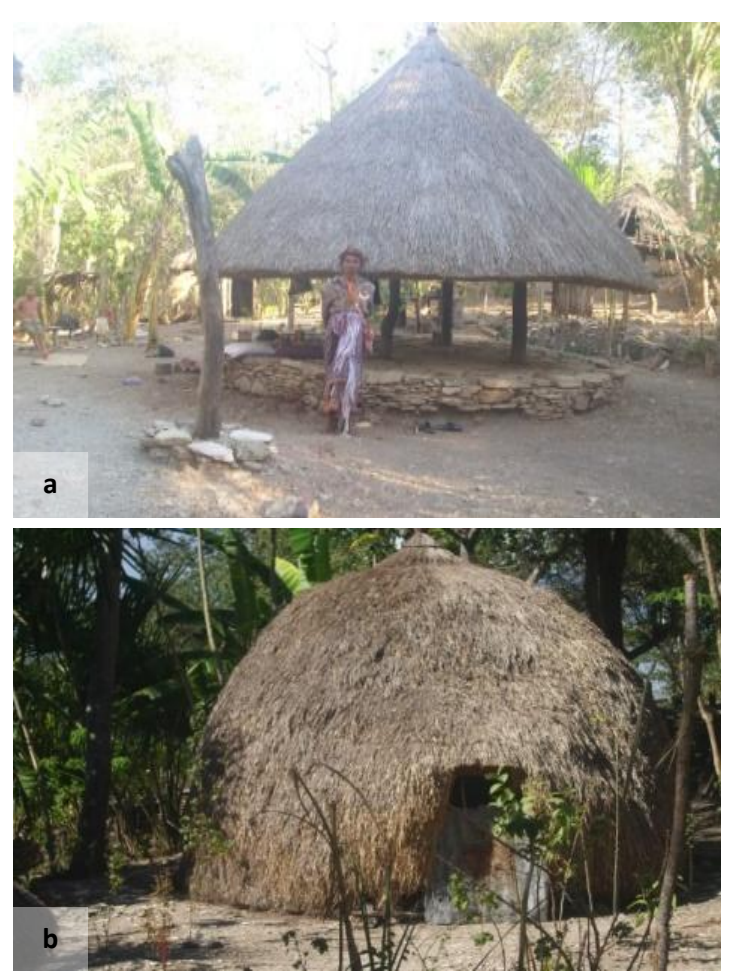

Figure 1. The Traditional House of Boti

a) Lopo (house for men), and b) Ume kbubu (House for women)

Boti tribal community lives in small area in Timor Tengah Selatan Regency (TTS). Administratively, Boti live in Ki'e Sub-district in TTS regency. Boti is the indigenous tribal community of western Timor Island, the descendant of Dawan or Sonbai. They called their group as atoin meto (men who live in semi arid to arid region). This community uses Dawan language for daily communication, in which recent population number was calculated about 77 households or 316 people. The Boti man never cut their hair and practicing many aspect 
of life following traditional role and using traditional equipments and tools.

The living system is unique. For a long time, this tribal community has been visited by tourist, especially foreign tourist. Based on the visitor guest records which area stored in Usif house, reason to visit Boti villages was numerous, include experiencing local tradition, landscape and get spiritual permission from king of Boti (the Usif Boti). Many visitors believe that kings have spiritual and supernatural power which is important for many objectives and purposes of the visitors to Boti. The main livelihood of villages in Boti is semi arid agricultural.

\section{Lands and Vegetation}

Boti located at the karsts area in secondary lowland forest area. The highest location of Boti villages located at $400 \mathrm{~m}$ asl. While there are no precise climate and rainfall data, it seems that the rainfall in Boti was sufficiently support semiarid agricultural system. Some area a fertile lands and many indigenous plant to Timor Island was found in Boti forest area. The majority of lands were used as crop cultivation and plantation. Soil was fragile and landslide easily occurs. In rainy season, accessibility to Boti was difficult because few roads were asphalted. The accessibility to the community can be said not easy ways. While there are limitation, live in Boti was harmonious with nature. The community of Boti is able to maintain environmental diversity. The harmony of Boti life is a representative the balance between human community, human and nature, and human and creator [11].

Forest of Boti community is integral part of forest [11] in Timor Island. Forest of Timor Island seems to be unique because some plant has origins from Australasia region, while other origins from Sundaland (Asia continental). Eucalyptus alba or hu'e found abundance in Timor, especially in Boti forest area. This species shows close relationship with the species in Australia [7]. Other species such as Pteracarpus Indicus or locally called matani shows close relationship with some species in India and Asia continent. Recently, such forest was limited in Indonesia, and therefore the existence of such forest was important. The management of forest through traditional knowledge is particularly important. In Indonesia, it is often common that local community manage natural resources, including community forest and home garden using traditional knowledge approach [12]

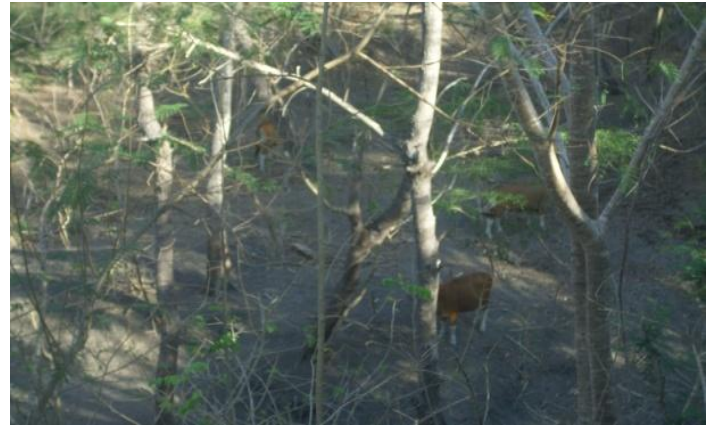

Figure 2. Forest of Boti

Halaika is an animism belief in Boti community; in which community belief the existence of Uis Neno and Uis Pah, despite the existence of community ancestor. According to Boti community, maintaining good relationship and communication with ancestor is an essential prerequisite to live in harmony, and perhaps even personal spirituality - among Boti community. Fundamentally, the belief of Boti respect to the natural balance, in which community prosperity can be only achieved if human respect to nature and able to maintain environment. The friendship of human-nature was important. Nature was viw3d as a system in which all of the resources are produced to enhance human prosperity and generation sustainability.

In many areas with traditional knowledge and local wisdom, biodiversity are relatively conserved by local people [12]. Local belief often provides spiritual power and increase the awareness of local people to participate in conservation [13]. In the perspective of tourism, this is become the significant tools to increase resources conservation to provides good attraction and enhance the tourist satisfaction. The local knowledge to conserve many indigenous plants for food and cultural needs has potentiality to integrate in rural tourism program [14].

\section{Tourism Resources in Boti}

Tourism resources both cultural and natural are important in tourism development. In many areas in Indonesia, however, the potentiality of tourism resources for tourism development rarely discussed intensively to provide comprehensive basic data related to tourism resources. Boti has numerous tourism resources, ranging from natural to cultural resources. Some of them are listed follow. 


\section{Indigenous landscapes}

The panorama of Boti villages and its surrounding area was hilly with many indigenous plants. The territory of Boti especially shows green area in semi arid and dry environment of Timor Island. Landscape scenery and relatively cool climates in semi arid regions are the main reason for tourist to visit Boti. This feature becomes important aspect that attract tourist to come to Boti. Psychologically, there are widely report on the impact of environmental quality and tourist desire to visit particular area with high quality of landscape [15].

\section{Handicraft}

The handicraft product of local community in Boti has specific characters and motif, in which it has uniqueness value (Fig. 3 ). Handicrat is the representative of ethnobotanical knowledge of local people on the uses of bio-resources for numerous daily equipment and art product which are interesting among tourist. There are bag, accessory, statues, and tais.

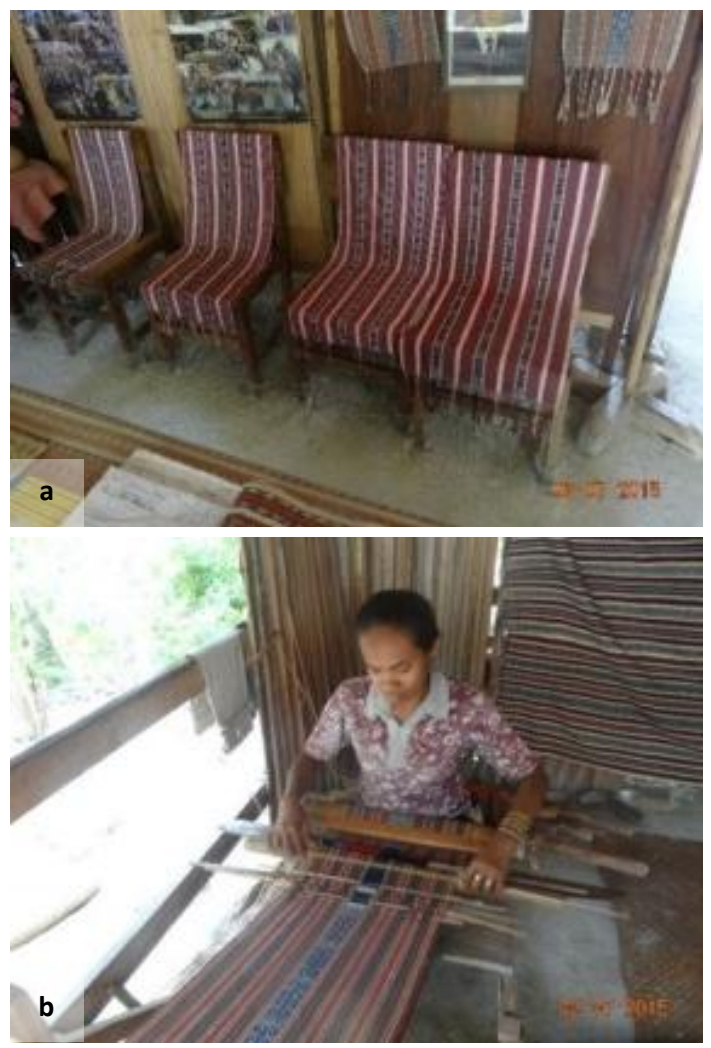

Figure 3. Boti Feminine Crafts

a) Traditional woven fabric for chair cover, and

b) Woman weaving traditionally

\section{King Boti Palace}

It is locally called sonaf, is the magnet of tourist who visits Boti. Sonaf was established behind lopo and used to accept guest or community meeting. The entire problem related to adat was also solved in sonaf and lopo.

\section{Boti's Traditional House}

It is locally called ume kbubu and was house of female, especially to conduct many daily works of women. Lopo was used by men to support their activity. These building were established with rich philosophy value. Philosophically, it is vertical and horizontal architecture. All of the material was collected from internal area of Boti Village. These influence the forest resources in Boti area which was conserved. Besides provides materials for building, forest of Boti community also provides food and medical plant material.

\section{Some Plants in Boti Forest}

The plants in Boti Forest have potentiality as tourism object. As far, 77 plant species was found to be used by people in Boti [16]. This is become the crucial natural resources for Boti community. Plant has numerous function, ranging from food, medical, material for constriction, and forage. There are need to be more exploration on the ethnobotanical aspect of plant-human in Boti.

\section{Live Philosophy}

Pattern and behavior which area influenced by local belief called Halika. Boti is rich in term of intangible heritage, including culture. It is become the potential sources for tourism development.

As far, tourism accommodation is absent in Boti villages. There are however, available house which area able to use by tourist.

\section{Remoteness and Area Accessibility}

Boti community lives in remotes area in Timor Island. The road to Boti was poor and few of them asphalted. Many roads are still constructed in open soil and gravel. Boti especially is accessible in dry periods and very difficult to access in rainy season. Boti is accessible by motor bike and car. Roads are important aspect for human and tourism movement. In the perspective of destination planning, road is the corridors which are provide numerous functions to the development of destination. There are no modern buildings in Boti villages. Machine and electronic instrument (i.e. radio, television, and internet) was absent. In the perspective of government and moderns economic, Boti can be 
classified as less developed area in Timor Islands. However, in the perspective of human psychology, Boti is sustainable community, in which resources suport for human daily life continue without disturbance. There is prosperity among Boti community.

Education and health facility was absent Medical aspect in the community was performed through traditional knowledge, especially the usage of numerous plans as medical material. The role of traditional knowledge was dominant in Boti community. It is especially common among local community throughout the world. The benefit of such knowledge recently has been identified to enhance the sustainability used of natural resources and therefore contribute to the sustainable development. Indigenous knowledge of Boti community to conservation has been more impressive.

\section{Ecotourism development}

Boti tribal community in Timor Island has potential resources for tourism development. Ecotourism seems to be the important form of tourism in Boti. Ecotourism is the responsible travel to natural environment, while it is also provides attention to the local community development [17]. In the perspective of ecotourism development, Boti provides ideal ecotourism destination. There are, however, tourism code of conduct was needed. It is especially important in ecotourism to enhance the sustainability of tourism.

While there are many limitation to access Boti community, tourist travel to Boti grows significantly. The remoteness, natural and cultural aspect of Boti seems to be attractive to tourist. The Boti community has been visited by international tourist for over 20 years, but there are no significant impacts of tourism to the indigenous community. These imply that tourism development should be designed to enhance community prosperity.

For the future development of tourism in Boti, the comprehensive study and analysis was needed. It is especially important to driven tourism development in sustainable manner. Scholar point out that tourist activity can be invasive and disturb the cultural aspect of local people. A lot of number and uncontrolled tourist also contribute to the environmental disturbance. In Boti, strengthening code of conduct in tourism is especially important and should be promoted and implemented.
Tourism is driven by attraction [18], and Boti has advantages due to the community has natural and cultural richness which area important for attraction. There are, however, should be understood that attraction and tourism programs should be able to support and enhance the local culture, tradition and support environmental conservation. In such a case, the cooperation and local community participation in tourism development is prerequisite for the sustainable tourism in Boti. Local community participation in tourism development can be very positive in term of promoting development in remotes area, including Boti. Furthermore, it is not sufficient for local government to solve many tourism infrastructure limitations in Boti, since there are still many region in Timor still less developed. In such case, community involvement in develop-ment was important. Ecotourism seem to be significant form of tourism in Boti.

\section{CONCLUSION}

The Boti community in Timor Island has much uniqueness, natural and cultural resources which are important for tourism development. The complex interaction of social, cultural and natural aspect and impact to the live in harmony in Boti are considered important to attract tourist. The recent vegetation Boti was preserved successfully through indigenous knowledge and local wisdom in Boti community. It supports the biodiversity conservation of semi arid region in Timor Island. The Boti community and its settlement are relatively difficult to reach.

\section{REFERENCES}

[1] Soebagyo, 2012. Indonesia tourism development strategy. Liquidity Journal 1(2), 153-158.

[2] Müller, D. K. and B. Jansson (Eds). 2006. Tourism in peripheries: perspectives from the far north and south. CABI.

[3] Gun, C. A. and T. Var. 2002. Tourism planning: basic principles and cases. Routledge. New York.

[4] Smith S. L. 1994. The tourism product. Annals of tourism research 21(3), 582-595.

[5] Oh, C. O. 2005. The contribution of tourism development to economic growth in the Korean economy. Tourism Management 26(1), 39-44.

[6] Pearce, D. G. 1985. Tourism and environmental research: a review. International Journal of Environmental Studies 25(4), 247-255. 
[7] Monk, K. A., Y. De Fretes and G. Reksodiharjo-Lilley. 2012. Ecology of Nusa Tenggara and Maluku Vol. 5. Tuttle Publishing. Vermont.

[8] Fallon, F. 2001. Conflict, power and tourism on Lombok. Current Issues in Tourism, 4(6), 481-502.

[9] Ministry of Economy. 2011. Master Plant for Acceleration and Development of National Economic year 2011-2025. Ministry of Economy. Jakarta.

[10] Fuah, A. M. 2013. Paradise in Timor Island TTS Regency - prospective land for agrifarming, exotic place for adventure. Gramedia Pustaka Utama. Jakarta.

[11] Cunningham, S., S. J. Attwood, K. S. Bawa, T. G. Benton, L. M. Broadhurst, R. K. Didham and D. B. Lindenmayer. 2013. To close the yield-gap while saving biodiversity will require multiple locally relevant strategies. Agriculture, Ecosystems and Environment 173, 20-27.

[12] Rahu, A. A., K. Hidayat, M. Ariyadi and L. Hakim. 2014. Management of Kaleka (traditional gardens) in Dayak community in Kapuas, Central Kalimantan. International Journal of Science and Research 3(3), 205210.

[13] Colding, J. and C. Folke. 2001. Social taboos: "invisible" systems of local resource management and biological conservation. Ecological applications 11(2), 584-600.

[14] Hakim, L. 2014. Etnobotani dan manajemen kebun-pekarangan rumah: ketahanan pangan, kesehatan dan agrowisata. Selaras. Malang.

[15] Fridgen, J. D. 1984. Environmental psychology and tourism. Annals of Tourism Research 11(1), 19-39.

[16] Benu, A.N. 2013. Plant and its Use in the village Boti Tradition - West Timor, Indonesia. Bebali Foundation. Bali.

[17] Ceballos-Lascurain, H. 1996. Tourism, ecotourism, and protected areas: The state of nature-based tourism around the world and guidelines for its development. IUCN.

[18] Inskeep, E. 1991. Tourism planning: an integrated and sustainable development approach. Van Nostrand Reinhold. New York. 